\section{Describing a drug's charge}

\section{Gordon C.K.Roberts}

Quantum Pharmacology, 2nd Edn.

By W.G. Richards

Butterworth: 1983. Pp.273. £25, \$59.95.

THE basic objective of molecular pharmacology was outlined by John Locke, in his Essay Concerning Human Understanding (1690):

Did we know the mechanical affections of the particles of rhubarb, hemlock, opium and a man, as a watchmaker does those of a watch, ... we should be able to tell beforehand that rhubarb will purge, hemlock kill and opium make a man sleep . . . .

Over the years, much effort has been devoted to investigating the "mechanical affections"' which determine drug specificity; with the development of structural and molecular biology, the past thirty years in particular have seen signal advances in our understanding of drug action. Dr Richards's book (the second edition of a work first published in 1977) is concerned with the most recent phase of this continuing effort, in which the methods of theoretical chemistry are brought to bear on the attempt to relate specific structural features of the drug molecule to its biological effects.

The first part of the book (114 pages) provides a wide-ranging but unfortunately rather superficial outline of some basic pharmacology. This is designed as an introduction for theoretical chemists, but they would probably be better advised to refer to one of several good introductory texts which are available. The second part (51 pages), on the other hand, is an excellent and lucid introduction to molecular orbital calculations which will be invaluable to any biologist venturing into this area for the first time.

In the final part ( 70 pages) we come to the heart of the book, where the applications of quantum chemistry to pharmacology are discussed; as one would expect, it is here that the greatest changes from the first edition are to be found. A substantial number of up-to-date examples are discussed in a helpful and reasonably critical way. These range from studies of drug conformation and of electron distribution and electrostatic potential, to correlations between activity and molecular orbital parameters. All this is presented very clearly, and one could only ask for more; additional references up to the end of 1981 are given in the excellent bibliography.

In this edition there is a new chapter on “Enzymes as Receptors", but only of eight pages in length. This area has been very active in recent years. However, much of the best of this work has largely involved "classical" potential functions rather than molecular orbital calculations, and these "classical" calculations are not discussed here. It is of course easy to castigate an author for not writing a different book, but a more rounded picture of the contributions of theoretical chemistry to pharmacology would have emerged if both kinds of calculation had been included.

Comparison of the first and second editions gives an impression of the steady progress in this field during the intervening years. It is clear that molecular orbital calculations now have an established place among the tools of the molecular pharmacologist, and Dr Richards's book continues to provide a useful introduction to their use.

Gordon C.K. Roberts is in the Division of Molecular Pharmacology, National Institute for Medical Research, London.

\title{
Landmarks in science
}

Great Scientific Experiments: 20 Experiments that Changed our View of the World by Rom Harré (Phaidon Press), is now available in paperback from Oxford University Press; price $£ 3.50$

The author considers key experiments in the history of science from a methodological and theoretical point of view. The work of Isaac Newton on the nature of colours is one of the subjects discussed. Below: The design of one of Newton's experiments, shown in the book.

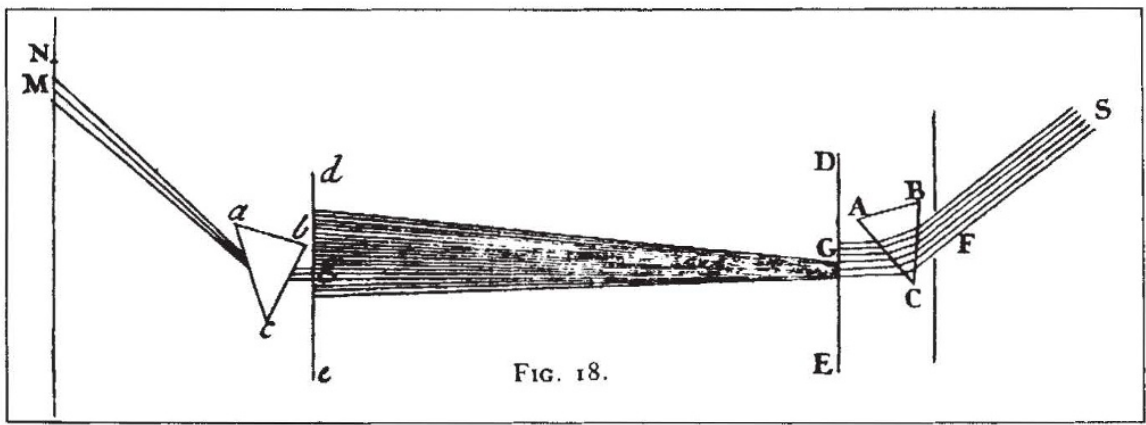

The separation of rays of different 'refrangibility'. (From Opticks 1721 edition, book I, part I, table iv, fig. 18). $S$ is the source of white light. In prism ABC the rays of different refrangibility are separated. The screens DE and de serve to separate progressively purer colours.

\section{Empowered to set standards}

\author{
Alastair Hay \\ OSHA and the Pritics of Health \\ Regulation. \\ By David P. McCaffrey. \\ Plenum: 1982. Pp.192. \$29.40, £19.15.
}

WHO regulates the regulators? Is it industry or public pressure groups? Or does the bureaucracy in a government agency police itself?

The answer to these questions usually depends on your position. Industrialists might be expected to feel that pressure groups have too much influence, whereas public interest groups are often the first to accuse industry of using unfair lobbying tactics. Sandwiched in between are the officials in the regulatory agency itself. Do they allow themselves to be brow-beaten and take the easy way out, or do they genuinely seek an answer which is in the public interest?

Whatever the decision, it usually fails to please all concerned, as David McCaffrey points out in his review of decision-making in the US Occupational Safety and Health Administration (OSHA). In a remarkable and very readable book, McCaffrey analyses the decisions made by the agency in the ten-year period 1971-1981. But it is his approach to the issue which makes his book unique. Rather than merely documenting decisions and the reactions to them, he considers what the outcome would have been had industry, public pressure groups or bureaucratic self-interest arranged the outcome.

A comparative fledging by agency standards, OSHA was born in the era of public concern over hazards in the work place. The Occupational Safety and Health Act of 1970 established the agency and charged it with ensuring that no worker should "suffer material impairment of health or functional capacity" from toxic chemicals at work

Has it discharged that obligation? Only in part. There are some recognizable successes but many failures too. The reasons for this are not hard to find; with President Reagan anxious to "deregulate" industry the message to the regulatory agencies is a simple "hands off". And the appoint ment of people of like mind to head OSHA and the Environmental Protection Agency only helped to underline the message.

But such pressure was also evident under the Carter Administration, the imposition of cost-benefit analysis - lives saved versus cost to industry - doing more than anything to weaken the power of the regulatory agencies. For example, in 1977 the 